\title{
KNOWLEDGE, ATTITUDE AND PRACTICE (KAP) OF RUBELLA VACCINATION IN ADOLESCENT GIRLS ATTENDING GYNAECOLOGY OPD AT BRD MEDICAL COLLEGE, GORAKHPUR
}

\author{
Seema Kumari ${ }^{1}$, Renu Sangal ${ }^{2}$, Aradhana Singh ${ }^{3}$, Harish Chandra Tiwari ${ }^{4}$, Reena Srivastava ${ }^{5}$, N. R. Sharma ${ }^{6}$ \\ ${ }_{1}^{1}{ }^{\text {rd }}$ Year Junior Resident, Department of Obstetrics and Gynaecology, BRDMC, Gorakhpur. \\ ${ }^{2}$ Associate Professor, Department of Obstetrics and Gynaecology, BRDMC, Gorakhpur. \\ ${ }^{3}$ Assistant Professor, Department of Obstetrics and Gynaecology, BRDMC, Gorakhpur. \\ ${ }^{4}$ Lecturer (Health Education), Department of Obstetrics and Gynaecology, BRDMC, Gorakhpur. \\ 5 Professor and HOD, Department of Obstetrics and Gynaecology, BRDMC, Gorakhpur. \\ ${ }^{6}$ Professor, Department of Obstetrics and Gynaecology, BRDMC, Gorakhpur.
}

\begin{abstract}
\section{BACKGROUND}

Rubella, also called German measles, is a disease of childhood. In the absence of pregnancy, it is usually clinically manifested as a mild self-limited infection. But a woman infected with the Rubella virus during the early stage of pregnancy has a $90 \%$ chance of transmitting it to the foetus. The virus can cause hearing impairments, eye and heart defects and brain damage in newborns, and even spontaneous abortion and foetal deaths. Of the 1,10,000 children born with CRS every year globally, an estimated 40,000 cases occur in India alone. A single dose of Rubella vaccine gives more than 95\% long-lasting immunity.

Aims and Objectives- To study about Knowledge, Attitude \& Practice (KAP) on Rubella vaccine among adolescent girls attending GYN OPD of BRD Medical College, Gorakhpur and the factors influencing KAP towards Rubella vaccination among adolescent girls.
\end{abstract}

\section{MATERIALS AND METHODS}

This descriptive study was done in the Department of Obstetrics and Gynaecological OPD at BRD Medical College, Gorakhpur, among adolescent girls. Among these adolescent girls, those who gave informed consent to participate in the study were interviewed by using a pre-structured questionnaire.

\section{RESULTS}

There were $40.10 \%$ of participants who had heard of Rubella previously. Of these, the most common source of information was books and television. The Rubella vaccine was known to $13.02 \%$ of the participants. Nobody in the study was Rubella immune.

\section{CONCLUSION}

Some lacunae in knowledge of the participants were seen in this study. Information to young women and our whole society should be improved and our aim should be to increase the motivation towards use of prevention methods such as taking the Rubella vaccine.

\section{KEYWORDS}

Knowledge, Attitude and Practice (KAP) Study; Rubella Vaccine; Congenital Rubella Syndrome (CRS).

HOW TO CITE THIS ARTICLE: Kumari S, Sangal R, Singh A, et al. Knowledge, attitude and practice (KAP) of Rubella vaccination in adolescent girls attending gynaecology OPD at BRD Medical College, Gorakhpur. J. Evolution Med. Dent. Sci. 2017;6(60):4435-4438, DOI: $10.14260 /$ Jemds/2017/958

\section{BACKGROUND}

According to the World Health Organisation (WHO), "a single dose of Rubella vaccine gives more than 95\% long-lasting immunity." All children aged nine months and 15 years will be administered a single dose of the combination vaccine. India has set an ambitious target of eliminating measles and controlling congenital Rubella syndrome (CRS), caused by the Rubella virus, by $2020 .{ }^{1}$ Rubella, also called German measles, is a disease of childhood that has markedly declined in incidence in North America since the introduction of routine childhood Rubella vaccination.

Financial or Other, Competing Interest: None.

Submission 21-06-2017, Peer Review 15-07-2017,

Acceptance 21-07-2017, Published 27-07-2017.

Corresponding Author:

Seema Kumari,

\#SS-2/643/D 1, LDA Colony Kanpur Road,

Lucknow, Uttar Pradesh.

E-mail: sams.kgmu@gmail.com

DOI: $10.14260 /$ jemds $/ 2017 / 958$
In the absence of pregnancy, it is usually clinically manifested as a mild self-limited infection. But a woman infected with the Rubella virus during the early stage of pregnancy has a $90 \%$ chance of transmitting it to the foetus. The virus can cause hearing impairments, eye and heart defects and brain damage in newborns, and even spontaneous abortion and foetal deaths. Of the 1,10,000 children born with CRS every year globally, an estimated 40,000 cases occur in India alone.2,3,4

Rubella Vaccine Live, attenuated (R-VAC) (Lyophilised) is prepared using Wistar RA 27/3 strain Rubella vaccine virus. This vaccine virus is propagated on human diploid cells (HDC). The vaccine is lyophilised and is provided with diluent. Each single human dose when reconstituted in a volume of $0.5 \mathrm{~mL}$ contains not less than 1000 CCID50 of live virus particles. Stability data has shown that the vaccine retains the potency of 1000 CCID50 per dose after 1 week at $37^{\circ} \mathrm{C}^{5,6,7}$ 


\section{Justification}

In spite of availability of very effective vaccine against Rubella, acceptance of Rubella vaccination is very low in our setup.

The purpose of this study was to explore factors influencing acceptance of Rubella vaccine.

\section{Aims and Objectives}

To study Knowledge, Attitude \& Practices on Rubella vaccine among adolescent girls attending GYN OPD of BRD Medical College, Gorakhpur and the factors influencing knowledge, attitude, practices towards rubella vaccination among adolescent girls.

\section{MATERIALS AND METHODS}

\section{Study Setting}

Department of Obstetrics \& Gynaecology, BRD Medical College, Gorakhpur.

\section{Study Unit}

Adolescent girls attending GYN OPD of BRD Medical College, Gorakhpur.

\section{Study Design}

Descriptive study.

\section{Sample Size}

$\mathrm{n}=4 \mathrm{pq} / \mathrm{l} 2=384$, Assuming $10 \%$ non-responders, final sample come out to be $384+39=423$.

Study Duration- 12 months.

\section{Methodology}

- Adolescent girls attending OPD were asked to participate in the study. Among these adolescent girls, those who gave informed consent to participate in the study were interviewed by using a pre-structured questionnaire.

- Sampling technique is purposive sampling. Adolescent patients with unstable vitals not included in the study.

\section{RESULTS}

\begin{tabular}{|c|c|c|}
\hline Age (Years) & Number (N) & Percentage (\%) \\
\hline $10-13$ & 58 & 15.10 \\
\hline $14-16$ & 135 & 35.16 \\
\hline $17-19$ & 191 & 49.74 \\
\hline \multicolumn{3}{|c|}{ Background } \\
\hline Rural & 314 & 81.78 \\
\hline Urban & 70 & 18.22 \\
\hline \multicolumn{3}{|c|}{ Religion } \\
\hline Hindu & 265 & $69.01 \%$ \\
\hline Muslim & 79 & $20.58 \%$ \\
\hline Sikh & 28 & $07.29 \%$ \\
\hline Christian & 12 & $03.12 \%$ \\
\hline \multicolumn{3}{|c|}{ Education (Subjects) } \\
\hline $5^{\text {th }}$ & 59 & 15.37 \\
\hline $8^{\text {th }}$ & 62 & 16.14 \\
\hline $10^{\text {th }}$ & 80 & 20.84 \\
\hline $12^{\text {th }}$ & 100 & 26.04 \\
\hline
\end{tabular}

\begin{tabular}{|c|c|c|}
\hline Graduation & 83 & 21.69 \\
\hline \multicolumn{3}{|c|}{ Education (Father) } \\
\hline Illiterate & 36 & 09.37 \\
\hline $5^{\text {th }}$ & 57 & 14.84 \\
\hline $10^{\text {th }}$ & 77 & 20.05 \\
\hline $12^{\text {th }}$ & 158 & 41.15 \\
\hline Graduate & 56 & 14.54 \\
\hline \multicolumn{3}{|c|}{ Education (Mother) } \\
\hline Illiterate & 134 & 34.90 \\
\hline $5^{\text {th }}$ & 58 & 15.10 \\
\hline $10^{\text {th }}$ & 133 & 34.64 \\
\hline $12^{\text {th }}$ & 38 & 9.89 \\
\hline Graduate & 21 & 5.49 \\
\hline \multicolumn{2}{|c|}{ Socioeconomic Status } \\
\hline Upper Class & 8 & 02.83 \\
\hline $\begin{array}{c}\text { Upper Middle } \\
\text { Class }\end{array}$ & 80 & 20.83 \\
\hline Middle Class & 131 & 34.11 \\
\hline $\begin{array}{c}\text { Lower Middle } \\
\text { Class }\end{array}$ & 126 & 32.81 \\
\hline Lower Class & 39 & 9.42 \\
\hline Table 1. Sociodem &
\end{tabular}

Table 1. Sociodemographic Profile of Subjects Interviewed for KAP Study of Rubella Vaccination

\begin{tabular}{|c|c|c|}
\hline Rubella Infection & Number (N) & Percentage (\%) \\
\hline Yes & 154 & 40.10 \\
\hline No & 230 & 59.90 \\
\hline Total & $\mathbf{3 8 4}$ & $\mathbf{1 0 0}$ \\
\hline
\end{tabular}

Table 2. Status of Knowledge of Rubella Infection among Subjects Interviewed for KAP Study of Rubella Vaccination

\begin{tabular}{|c|c|c|}
\hline Rubella Vaccine & Number (N) & Percentage (\%) \\
\hline Yes & 50 & 13.02 \\
\hline No & 334 & 86.98 \\
\hline Total & $\mathbf{3 8 4}$ & $\mathbf{1 0 0}$ \\
\hline
\end{tabular}

Table 3. Status of Knowledge of Rubella Vaccine among Subjects Interviewed for KAP Study of Rubella Vaccination

\begin{tabular}{|c|c|}
\hline Source of Knowledge & Rubella \\
\hline Newspaper & $20(12.99 \%)$ \\
\hline Radio & $10(6.49 \%)$ \\
\hline TV & $50(32.47 \%)$ \\
\hline Internet & $0(0.0 \%)$ \\
\hline Books & $64(41.55 \%)$ \\
\hline Health Worker & $10(6.49 \%)$ \\
\hline Friends & $0(0.0 \%)$ \\
\hline Relatives & $0(0.0 \%)$ \\
\hline Magazine & $0(0.0 \%)$ \\
\hline Total & 154 \\
\hline
\end{tabular}

Table 4. Source of Knowledge of Rubella Vaccine among Subjects Interviewed for KAP Study of Rubella Vaccination 


\begin{tabular}{|c|c|c|c|}
\hline Sl. No & Question & Yes N (\%) & No N (\%) \\
\hline 1 & Is Rubella an infectious disease? & $80(20.83 \%)$ & $304(79.17 \%)$ \\
\hline 2 & $\begin{array}{c}\text { Do you know that Rubella infection during pregnancy causes adverse effect on } \\
\text { foetus? }\end{array}$ & $50(13.02 \%)$ & $334(86.98 \%)$ \\
\hline 3 & During pregnancy Rubella infection causes heart disease, deafness, cataract. & $50(13.02 \%)$ & $334(86.98 \%)$ \\
\hline 4 & Is Rubella prevented by vaccine? & $50(13.02 \%)$ & $334(86.98 \%)$ \\
\hline 5 & Is Rubella diagnosed by investigation? & $45(11.71 \%)$ & $339(88.28 \%)$ \\
\hline \multicolumn{2}{|r|}{ Table 5. Knowledge of Sequelae of Rubella Infection among Subjects Interviewed for KAP Study of Rubella Vaccination } \\
\hline
\end{tabular}

\begin{tabular}{|l|c|c|c|c|c|}
\hline \multicolumn{1}{|c|}{ Item } & $\begin{array}{c}\text { Strongly } \\
\text { Disagree }\end{array}$ & Disagree & Can't say & Agree & Strongly Agree \\
\hline $\begin{array}{l}\text { 1. I think my guardians could pay for the } \\
\text { vaccine }\end{array}$ & $20(5.2 \%)$ & $76(19.79 \%)$ & $150(39.06 \%)$ & $98(25.52 \%)$ & $40(10.41 \%)$ \\
\hline 2. I would get the vaccine if it were for free & $10(2.6 \%)$ & $10(2.60 \%)$ & $20(5.20 \%)$ & $144(37.51 \%)$ & $200(52.08 \%)$ \\
\hline 3. It is not necessary for me to get vaccinated & $200(52.08 \%)$ & $104(27.08 \%)$ & $50(13.02 \%)$ & $10(2.6 \%)$ & $20(5.2 \%)$ \\
\hline $\begin{array}{l}\text { 4. Only sexually active women should receive } \\
\text { the vaccine }\end{array}$ & $70(18 \%)$ & $36(9.38 \%)$ & $150(39.06 \%)$ & $62(16.14 \%)$ & $62(16.14 \%)$ \\
\hline $\begin{array}{l}\text { 5. My parents would not allow me to get the } \\
\text { vaccine }\end{array}$ & $200(52.08 \%)$ & $100(26.04 \%)$ & $54(14.06 \%)$ & $15(3.90 \%)$ & $15(3.90 \%)$ \\
\hline $\begin{array}{l}\text { 6. I wish to get more information about Rubella } \\
\text { infection and Rubella vaccination }\end{array}$ & $20(5.2 \%)$ & $20(5.2 \%)$ & $40(10.91 \%)$ & $104(27.08 \%)$ & $200(52.08 \%)$ \\
\hline \multicolumn{7}{|c|}{ Table 6. Attitude towards Rubella Vaccination among Subjects Interviewed for KAP Study of Rubella Vaccination } \\
\hline
\end{tabular}

\begin{tabular}{|c|c|c|}
\hline Vaccination Status & Number (N) & Percentage (\%) \\
\hline Yes & 0 & 0 \\
\hline No & 58 & 37.66 \\
\hline Don't Know & 96 & 62.34 \\
\hline Total & 154 & 100 \\
\hline \multicolumn{3}{|c|}{ Table 7. Practice towards Rubella Vaccination among Subjects } \\
\hline
\end{tabular}

\section{DISCUSSION}

The aim of the study was to collect baseline data on knowledge on Rubella vaccine and also acceptability for vaccination in adolescent girls. There were $40.10 \%$ of participants that had heard of Rubella previously. Of these, the most common source of information was books and television. The Rubella vaccine was known to $13.02 \%$ of the participants. Over $85 \%$ of the participants had no knowledge of Rubella. In total, most of the participants in the sample were found to have a positive level of attitude towards the vaccine. Almost all participants wanted to know more about Rubella infection and its vaccines. In contrast to present study, in a study conducted by Juliana Costa Vieir et al (2011), although $69.9 \%$ of respondents said they knew what Rubella is, but actual knowledge of the disease was limited, with only $29.9 \%$ answering affirmatively when asked if they would recognise symptoms of Rubella infection. ${ }^{8}$

The knowledge regarding Rubella infection is maximum among age group of $17-19$ years that is $73.29 \%$, followed by age group of $14-16$ years that is $10.37 \%$. There was no knowledge of Rubella infection among early adolescents (1013 years).

The knowledge regarding Rubella vaccine is maximum among age group of $17-19$ years that is $25.69 \%$ followed by age group of $14-16$ years that is $0.74 \%$. There was no knowledge of Rubella infection among early adolescents (1013 years)
Individual participants who were educated up to $8^{\text {th }}$ class had no knowledge of Rubella infection. The knowledge regarding Rubella infection was maximum among patients who were educated up to graduation level (Rubella 93.98\%) followed by patients educated up to $12^{\text {th }}$ standard (70.0\%).

Individual participants who were educated up to $8^{\text {th }}$ class had no knowledge of Rubella vaccine. The knowledge regarding Rubella vaccine was maximum among patients who were educated up to graduation level (Rubella 36.14\%) followed by patients educated up to $12^{\text {th }}$ standard (Rubella 18.0\%).

Individual participants who belonged to lower class had no knowledge regarding Rubella infection. The knowledge regarding Rubella infection was maximum among participants who belonged to upper class socioeconomic status (Rubella 75\%) followed by participants who belonged to upper middle class and lower middle class socioeconomic status.

There was maximum knowledge regarding Rubella infection in urban background that is $71.43 \%$, followed by rural background that is $29.94 \%$.

Most common source of information in the present study was from books (80.64\%) and television (16.12\%). There is minimal role of health professional in the present study.

In the present study, only $13.02 \%$ of the participants had knowledge of Rubella vaccine. 
Despite poor knowledge in this study, the attitude towards the vaccine was overall positive and a majority believed it was necessary for them to receive the vaccine.

In the present study, $35.95 \%$ participants agreed that their parents pay for vaccine and $79.17 \%$ participants agreed for vaccination if it would be free of cost.

There was nobody in the study immunised against Rubella. Most of the participants wanted to immunise but due to lack of proper knowledge and financial problem they did not agree. In contrast to present study, in a study conducted by Juliana Costa Vieira et al (2011), a total of $94.5 \%$ of the respondents expressed willingness to be vaccinated for Rubella elimination. Rajagopal Rao Kodali et al (2015) in their study found attitude among college students was more towards child immunisation $(77.6 \%)$ followed by vaccination $(63 \%)$ and less about knowing of immunisation status (58.6\%). Attitude towards child immunisation, vaccination, knowing of immunisation status were $84.4 \% 0,73.2 \%$, and $70 \%$ among medical students in comparison to $70.8 \%, 52.8 \%$ and $47.2 \%$ among non-medical students.

In the present study, after assessing knowledge, attitude and practice of the participants, I was able to immunise 30 (7.8\%) participants against Rubella.

\section{CONCLUSION}

A majority of the participants in this study had a poor knowledge of Rubella, even if most had a positive level of attitude towards the Rubella vaccine. There is a need to improve the poor knowledge in order to change behaviour so that they will take the Rubella vaccine. Prescription of Rubella vaccine was hindered by the perceived parental concerns and was mostly relied on Government recommendations. Educational initiatives should be targeted towards both physician and parents and the Government should consider full subsidy to enhance vaccine uptake rate.

\section{REFERENCES}

[1] www.who.int/immunization/sage/en.

[2] Centers for Disease Control and Prevention. Progress toward control of Rubella and prevention of Congenital Rubella Syndrome Worldwide. MMWR 2009;59(40):1307.

http://www.cdc.gov/mmwr/preview/mmwrhtml/m m5940a4.htm. Accessed 2/9/2016

[3] Enders G, Nickerl-Pacher U, Miller E, et al. Outcome of confirmed periconceptual maternal Rubella. Lancet 1988;1(8600):1445-7.

[4] World Health Organization. A System for the prequalification of vaccines for UN supply. Available from: http://www.who.in t/immunization_standards/ vaccine quality/pq_system/en/.

[5] Miller E, Cradock-Watson JE, Pollock TM. Consequences of confirmed maternal Rubella at successive stages of pregnancy. Lancet 1982;2(8302):781-4.

[6] Cutts FT, Robertson SE, Diaz-Ortega JL, et al. Control of Rubella and congenital Rubella syndrome (CRS) in developing countries, Part 1: burden of disease from CRS. Bull World Health Organ 1997;75(1):55-68.

[7] Centers for Disease Control. Control and prevention of Rubella: evaluation and management of suspected outbreaks, Rubella in pregnant women, and surveillance for congenital Rubella syndrome. MMWR Recomm Rep 2001;50(RR-12):1-23.

[8] Vieira JC, Carvalho MT, Checchia RL, et al. Survey of Rubella knowledge and acceptability of Rubella vaccination among Brazilian adults prior to mass vaccination. Rev Panam Salud Publica 2011;30(4):335-41. 